\title{
THE QUALITY AND MEANING OF LIFE OF CANCER PATIENTS IN REMISSION: SOCIO-PSYCHOLOGICAL ASPECTS
}

\author{
Lilia Suchocka ${ }^{1}$, Katarzyna Jaroszek ${ }^{2}$, Elena Medvede- \\ va $^{3^{*}}$, Angelika Szczepanik ${ }^{4}$, Małgorzata Pasek ${ }^{2}$ \\ ${ }^{1}$ Jan Kochanowski University of Kielce \\ (5 Żeromskiego str., Kielce, Poland, 25-369) \\ ${ }^{2}$ University of Applied Sciences in Tarnow \\ (8 Mickiewicza str., Tarnow, Poland, 33-100) \\ ${ }^{3}$ Institute of Socio-Economic Studies of Population of the Federal Center \\ of Theoretical and Applied Sociology of the Russian Academy of Sciences \\ (32 Nakhimovsky prospect, Moscow, Russian Federation, 117218) \\ ${ }^{4}$ Institute of Biofeedback and Noo-psychosomatic \\ (13 Farmaceutyczna str., Lublin, Poland, 20-706) \\ *E-mail:e_lenam@mail.ru
}

For citation:

Suchocka L., Jaroszek K., Medvedeva E., Szczepanik A., Pasek M. The quality and meaning of life of cancer patients in remission: socio-psychological aspects. Narodonaselenie [Population]. 2021. Vol. 24. No. 3. P. 76-91. DOI: 10.19181/population.2021.24.3.7.

Abstract. The sense of the meaning of life is a subjectively felt, positive mental state. Suffering in chronic illness intensifies in a human being the sense of isolation and gives rise to emotions with that an individual often cannot cope. Such experiences are characteristic of the process of cancer remission. The sense of coherence strengthens the sense of coping with disease, which increases prospects of recovery. The article presents the results of the authors' research (103 respondents) on the quality and meaning of life of cancer patients in remission: socio-psychological aspects, indicators of the categories of «meaning of life», "responsibility», "consistency», and the latter is dominant at the stage of cancer remission in the studied cohorts. The survey was conducted on the basis of the methodology developed by the authors using the «Goal in Life» test (PIL) by J. K. Crumbaugh and J.J. Smith. Maholicka, as well as «The sense of coherence» by A. Antonovsky (SOC-29). The study showed that the group under survey had a fairly high level of indicators of the categories «meaning of life», «responsibility», "consistency», which did not depend on when the respondents were diagnosed with cancer, as well as the fact that the studied indicators reached higher values in women than in men. Interpersonal factors «meaning of life» and «responsibility» were identified as dominant in the study of the quality and meaning of life in relation to other socio-psychological factors.

Keywords: socio-psychological factors, quality of life, meaning of life, sense of responsibility, remission, health. 


\section{Introduction}

According to the latest data of the Polish National Cancer Registry, the numbers of people diagnosed with cancer were: 167,500 in 2018, 177,400 in 2019, and 182,500 in 2020. The above data show that an increase in the number of patients with cancer is observed every ear. It is estimated that almost 1,170,000 people in Poland live with cancer diagnosed within the last 15 years; 840,000 of them were diagnosed not later than 10 years ago [1]. The study group discussed in this paper was also diagnosed within 10 years (see Table 2).

Among women, the most frequent localizations of cancer, found in $15 \%$ of the population, are breast, lungs, and large intestine [1]. In the study group this type of cancer has been diagnosed in $14 \%$ of the respondents (see Table 2). The most frequent cancer in men is prostate cancer (20\%), which is characterized by the greatest dynamics of morbidity [1]. In the studied group, $14 \%$ of the patients suffered from prostate cancer. Lung cancer and large intestine cancer occur in $12 \%$ of the Polish population. In the study group, large intestine cancer, stomach cancer, liver cancer, kidney cancer, and bladder cancer were diagnosed in $14 \%$ of the respondents. The cited data show that the clinical characteristics of the study group reflect the general morbidity statistics for cancer in the population of Poland.

The greatest number of cancer cases in Poland was found in men at 55-79 years of age and in women at 50-74 years of age [1]. The similar age distribution (50-70 years) was observed in the study group (see Table 1).

The experience of cancer and of the whole treatment process is often connected with suffering and distress (even torment) which may be related to feeling physical pain, the sense of loss or being struck by misfortune, a threat to one's dignity, professional position or social role, fear of disability or change in one's appearance. This unfavorable experience has psychological effects (in the form of negative emotions), social effects (related to losing one's role or position in family and society), and spiritual effects (as a threat to one's existence), such an experience may lead to loss of the sense of meaning of life and to asking the question 'why me'? [2; 3; 4].

Patients with cancer experience numerous complaints which affect the quality of their lives and make everyday activities difficult. The complaints in question may include pain, weariness, sleeplessness, poor appetite, limited agility, easy fatigability, etc. These symptoms may increase psychological and existential suffering and lead to dejection, a sense of helplessness, of having no way out, and of becoming a burden to others (family, close ones) [5].

The current of existential psychology, developed from V.E. Frankl's logotherapy (the 3rd Viennese current in psychotherapy) and in Poland carried on by K. Popielski, conceives of the three dimensions of human existence: physical, psychological, and spiritual (noetic), while emphasizing the role of the sense of meaning of life and of the implementation of values in the functioning and development of an individual $[6 ; 7 ; 8]$.

The Polish expression for 'the meaning of life' is «sens życia» (by association with, e.g., a connotation of the French word 'sense', which means 'direction') and suggests activities leading in a certain direction or towards a certain purpose. The experience of the meaning of life is a subjectively felt positive mental state combined with an awareness of implementing values through which a person achieves his or her individual purpose in life. All human beings experience an inner need to achieve certain goals and, in consequence, subordinate many of their actions to these goals. In such a context, individual goals acquire value (grow meaningful) and become useful in achieving a definite main purpose in life $[7 ; 9]$.

Physically healthy people perceive their purpose in life in a different way than those aware of their chronic, incurable, or terminal disease. Achieving goals in life is related to fulfilling demanding requirements (strong inner motivation, self-discipline, deep self-awareness). Disease, suffering, living under constant threat, failures, a sense of 
meaninglessness of one's life trigger selfreflection thus helping to achieve higher goals [6]. Therefore, even if human beings are depleted of certain values due to limitations imposed by cancer, they still face the task of fulfilling the meaning of their lives - despite the disease [10].

The suffering related to cancer increases a person's sense of isolation and breeds emotions with which it is often difficult to cope. A patient may feel lack of meaning in his or her life and, as a result, cannot look towards the future or perceive a goal to achieve. The present study is an attempt to answer the key question posed by treatment providers: Is it possible, in the face of suffering, incurable disease or dying, to find meaning? [11; 12; 13]

To look closer at the phenomenon of stress resistance in patients with chronic illness, the authors of the present paper refer to the salutogenic model proposed by A. Antonovsky, in which an individual is believed to have the characteristics enabling him to meet the challenges of difficult or stressful situations and to perceive the reality and his situation as comprehensible and meaningful, and also to find resources and competences to overcome the difficulties. The author of the salutogenic model does not understand the sense of coherence as a psychological state or a personality trait; instead, he conceives the sense of coherence as a 'dispositional orientation' which is primary and fundamental, yet possible to shape and consolidate [14]. Antonovsky believes that persons with a high sense of coherence are more resistant and less prone to give in to difficulties in life, know where to turn for help and believe that the effort they make matters, is meaningful and important $[14 ; 15 ; 16]$.

\section{Materials and methods}

The study included 103 cancer patients in remission. The studied individuals came from Małopolska and Podkarpacie (southern regions of Poland) and were selected randomly. The participation in the study was voluntary and anonymous.

The study tools used in the project included the questionnaire devised by the authors to assess socio-demographic data and the following standardized methods: 1) PIL Test (Purpose in Life Test) by Crumbaugh and Maholick, used to evaluate (1) purpose in life, (2) meaning of life, (3) affirmation of life, (4) self-evaluation, (5) one's own assessment of meaning in his or her life, (6) freedom and responsibility, (7) attitude to death and to suicide [7]; 2) The Sense of Coherence Questionnaire (SOC-29) by A. Antonovsky, used to evaluate the components of the sense of coherence: (1) comprehensibility, (2) manageability, (3) meaningfulness [15]. The STATISTICA software was used to statistically analyze the study results.

While designing and conducting the study, the authors followed all the essential principles of good practice in scholarly research. The participation in the study was voluntary and the anonymity of the participants was guaranteed.

The aim of the study presented in this paper was an analysis of the level of the achievement of purpose in life and of the sense of meaning of life on the one hand, and the sense of coherence on the other, in individuals after their cancer treatment was completed.

The problem addressed by the study was the level of the sense of meaning and of purpose in life, the sources of the perception of meaning and purpose, as well as the sense of coherence in the studied cancer patient in remission. An additional aim was to analyze relationships in family, as perceived by the study participants, changes which occurred as a result of the experience of remission, and difficulties experienced by cancer patients.

In this connection, the following hypotheses were formulated: H1) The studied individuals positively evaluate the level of their relationships with their close ones in the family; H2) Values described as the most important in the life of the respondents in remission and the sources of their perceived meaning of life are important motivators to battle against the illness process; H3) Cancer remission is a situation in which 
the respondents experience difficulties and changes in their lives; H4) The levels of the sense of purpose and meaning of life differ in women and in men; H5) The relationships in the family affect the level of achieving goals and finding the meaning of life and that of the sense of coherence in the studied individuals.

The study group comprised 103

\section{Socio-demographic characteristics of the study group}

Table 1

Социально-демографические характеристики исследуемой группы

\begin{tabular}{|c|c|c|c|}
\hline \multicolumn{2}{|c|}{ Variable } & \multirow{2}{*}{$\frac{N=103}{86}$} & \multirow{2}{*}{$\frac{\%}{83,50}$} \\
\hline Gender & Women & & \\
\hline & Men & 17 & 16,50 \\
\hline \multirow[t]{5}{*}{ Age } & to 50 years & 28 & 27,23 \\
\hline & $51-60$ years & 24 & 23,33 \\
\hline & $61-70$ years & 25 & 24,27 \\
\hline & over 70 years & 18 & 17,4 \\
\hline & No data & 8 & 7,77 \\
\hline \multirow[t]{4}{*}{ Education } & University & 31 & 30,11 \\
\hline & Secondary & 40 & 38,83 \\
\hline & Vocational & 16 & 15,53 \\
\hline & Elementary & 16 & 15,53 \\
\hline \multirow[t]{3}{*}{ Place of residence } & City & 50 & 48,55 \\
\hline & Small town & 14 & 13,59 \\
\hline & Village & 39 & 37,86 \\
\hline \multirow[t]{5}{*}{ Marital status } & Unmarried & 20 & 19,42 \\
\hline & Husband & 67 & 65,05 \\
\hline & Widow/widower & 12 & 11,65 \\
\hline & Divorced & 3 & 2,91 \\
\hline & No answer & 1 & 0,97 \\
\hline \multirow[t]{2}{*}{ Children } & Yes & 74 & 74,76 \\
\hline & No & 26 & 25,24 \\
\hline \multirow[t]{7}{*}{$\begin{array}{l}\text { Professional activity/ } \\
\text { employment }\end{array}$} & Retired (old age pension) & 39 & 37,86 \\
\hline & Full-time employment & 28 & 27,18 \\
\hline & Disability pension & 22 & 21,36 \\
\hline & Part-time employment & 4 & 3,88 \\
\hline & Never worked professionally & 4 & 3,88 \\
\hline & Freelance work & 2 & 1,94 \\
\hline & Unemployment benefit & 1 & 0,90 \\
\hline
\end{tabular}

Source: the authors' own data. 
respondents, including $86(83.5 \%)$ women and 17 (16.5\%) men.

Most respondents were under 50 years of age and between 61 and 70 years, lived in cities, and completed secondary or university education.

In the study group, 67 patients $(65.05 \%)$ lived in a relationship, 20 patients (19.42\%) were unmarried, 12 patients (11.65\%) ere widowed, 3 patients (2.91\%) were divorced, and 1 patient did not answer the question concerning marital status.

Among the respondents, 74 (74.76\%) had children, while 26 (25.24\%) had no children. The professional activity or employment status of the studied patients was as follows: the greatest number of respondents 39 (37.86\%) were retired, 28 respondents (27.18\%) were employed full-time, 22 (21.36\%) receive disability pensions, 4 (3.88\%) were employed part-time, 4 (3.88\%) were never employed or worked professionally, 2 (1.94\%) worked freelance, and 1 (0.90\%) received an unemployment benefit.

\section{Results}

The study covered cancer patients in remission, after their treatment had been finished. For patients, however, this period is often not the moment when the treatment process has been actually completed. Cancer remission means that diagnostic tests do not show the presence of cancer cells in the body. In the case of cancer, it is difficult to determine the duration of remission. Remission may last many years, frequently even to the end of a patient's life; at other times, however, the time of remission may be much shorter and last only several days or weeks.

Depending on the course of remission, patients experience different psychological states, from a hope for health, to uncertainty, anxiety, and fear [10].

Data concerning the time from cancer diagnosis in the studied patients

Table 2

Таблица 2

Данные времени от постановки диагноза рака у обследованных пациентов

\begin{tabular}{|l|c|c|}
\hline \multicolumn{2}{|c|}{ Variables } & N \\
\hline \multicolumn{2}{|c|}{ Localization of cancer } \\
\hline Chest (breast cancer, lung cancer) & 55 & 53 \\
\hline $\begin{array}{l}\text { Head and throat (thyroid gland, head, } \\
\text { throat, larynx, lip) }\end{array}$ & 14 & 14 \\
\hline $\begin{array}{l}\text { Abdominal cavity (large intestine, stomach, } \\
\text { liver, kidneys, pancreas, prostate, bladder) }\end{array}$ & 14 & 14 \\
\hline Reproductive system & 9 & 9 \\
\hline Bones & 6 & 5 \\
\hline Skin & 3 & 3 \\
\hline Leukaemia & 2 & 2 \\
\hline Total & $\mathrm{N}=103$ & $100 \%$ \\
\hline & Diagnosis time & 22,33 \\
\hline Over 10 years & 23 & 24,27 \\
\hline 7-10 years & 25 & 19,42 \\
\hline 4-6 years & 20 & 30,10 \\
\hline to 3 years & 31 & 3,88 \\
\hline No answer & 4 & $100 \%$ \\
\hline Total & $\mathrm{N}=103$ & \\
\hline
\end{tabular}

Source: the authors' own data. 
The study group was diversified with respect to localization of cancer. The greatest number of the patients had suffered from breast cancer $(55 ; 53 \%)$, thyroid cancer $(14 \%)$, and cancer of pelvic organs (9\%).

The largest group of patients $(31 ; 30.10 \%)$ had cancer diagnosed not later than 3 years before the study; the least numerous were the patients with the diagnosis made between 4 and 6 year before the study.
Another variable considered in the study was assessment of their family relationships made by the respondents. Family provides important support to people who experience cancer. Figure 1 presents the results of the evaluation of relationships in the families of the respondents during cancer remission.

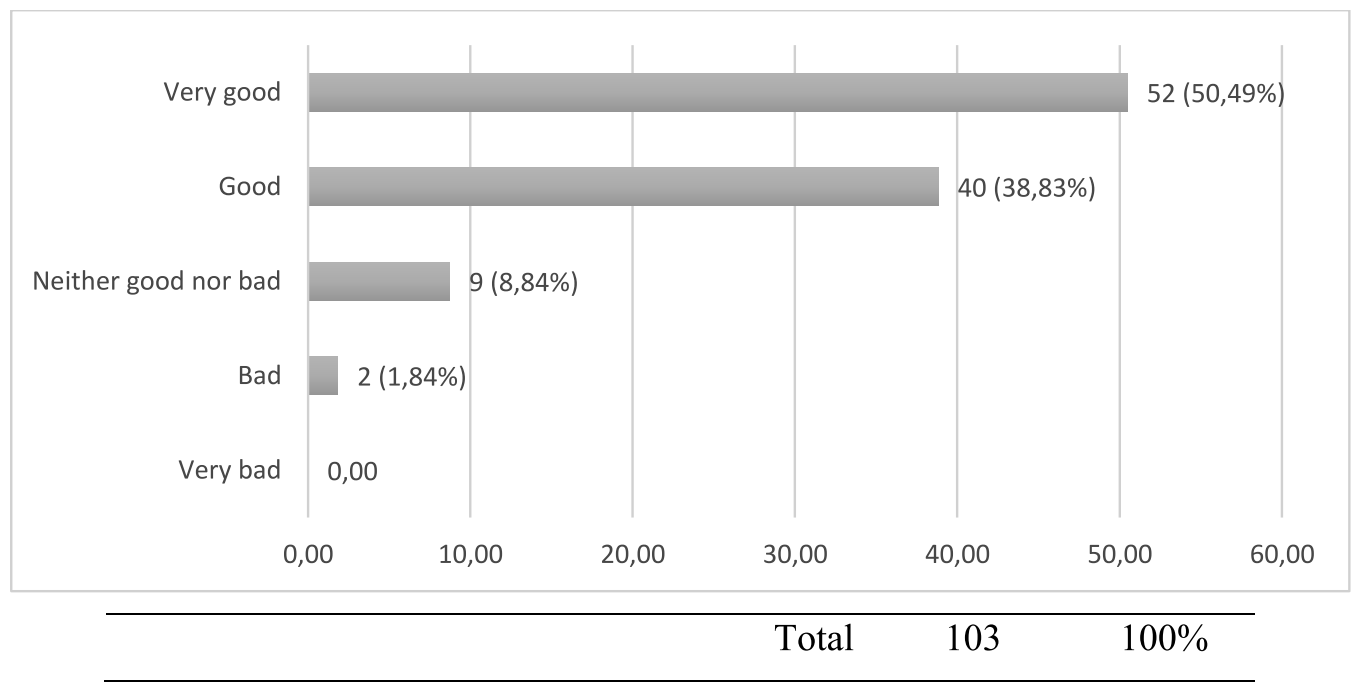

Fig. 1. Contacts and relationships of the respondents with their families

Рис. 1. Контакты и отношения респондентов со своими семьями

Source: the authors' own data

The tests we have conducted show that almost $90 \%$ of the respondents assessed their contact with their families as very good and good: 52 (50.49\%) respondents declared that their relationship with the family was very good, while 40 (38.83\%) respondents assessed such relationships as good. However, 9 (8.84\%) respondents evaluated their family relationships as indifferent (neither good nor bad), while 2 (1.94\%) negatively assessed their contact with family members; such a bad relationship may even exert a negative influence on their experience of cancer.

The specific character and quality of experiencing cancer is also influenced by the value hierarchy of the respondents, and this variable was also analyzed in the present study (Fig. 2). For the respondents, the most important values were health $(79.61 \%)$ and love $(49.51 \%)$, while 8 (7.77\%) respondents indicated, among others, religious faith, family, security of their family and close ones, and a desire to use well the time left to them. Value fulfillment is inseparably connected to searching for and experiencing the meaning of life. Another step in our analysis was to look at the sources of the meaning of life in the respondents in remission. 
Lilia Suchocka, Katarzyna Jaroszek, Elena Medvedeva, Angelika Szczepanik, Małgorzata Pasek

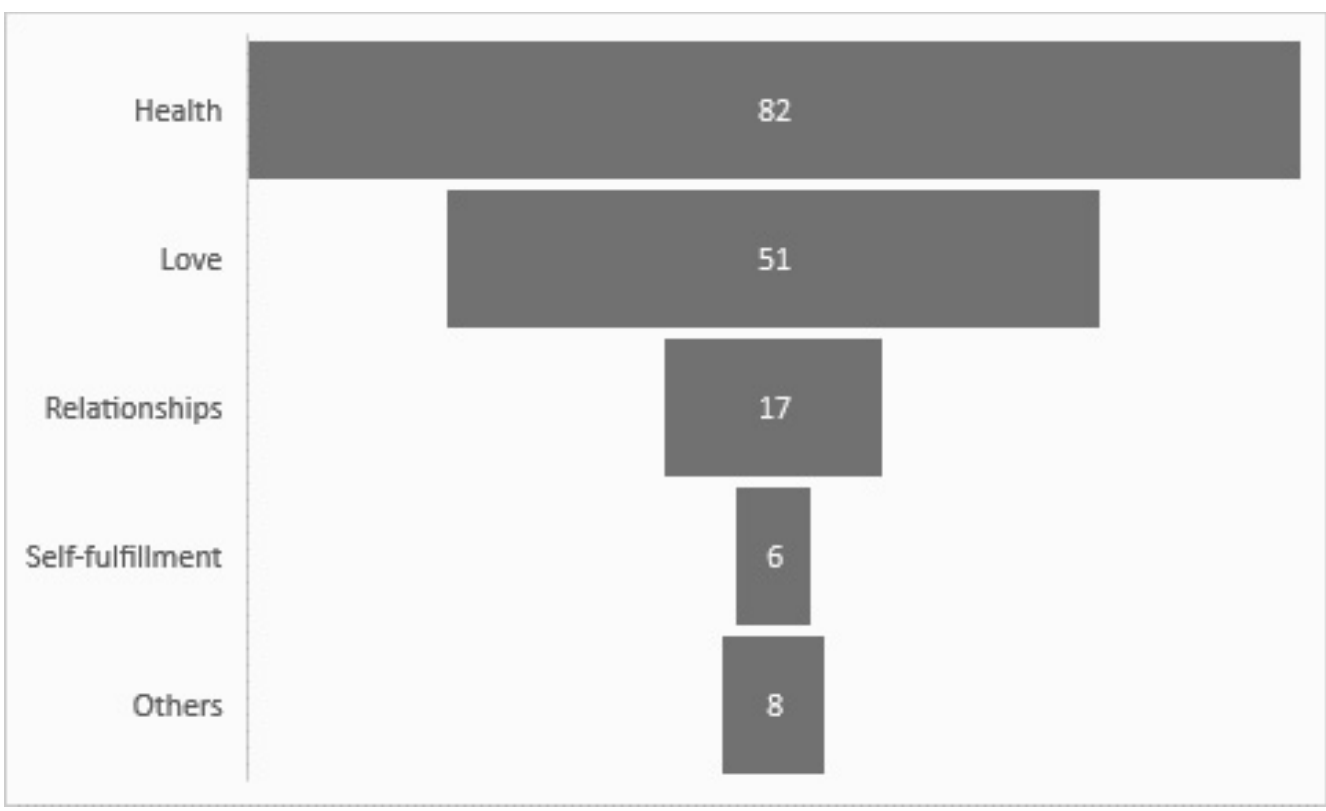

Fig. 2. The most important values in the respondents' lives, \%*

Рис. 2. Наиболее важные ценности в жизни респондентов, \%* 'The sum of percent values exceeds $100 \%$ because it was a multiple-choice question.

Source: the authors' own data.

Table 3 shows data on the sources which enable the respondents to perceive meaning in their lives. Asked about an important source of the meaning of life, as much as 74 (71.84\%) of the respondents indicated religious faith, which helps them to function during cancer remission. The second most important source was the sense of being needed, indicated by $56(54.37 \%)$ of the respondents. Love and relationships with others were the third most important source of the meaning of life during remission that was chosen by 48 (46.60\%) respondents.

\section{Perception of the meaning of life during remission}

Восприятие смысла жизни в период ремиссии

\begin{tabular}{|c|l|c|c|}
\hline Rank & \multicolumn{1}{|c|}{ Sources of the meaning of life during remission } & $\mathrm{N}=103$ & $\%^{*}$ \\
\hline 1. & Religious faith & 74 & 71,84 \\
\hline 2. & Sense of being needed by others & 56 & 54,37 \\
\hline 3. & Love, relationships with others & 48 & 46,60 \\
\hline 4. & Work & 28 & 27,18 \\
\hline 5. & Contact with nature and/or culture & 22 & 21,36 \\
\hline 6. & Experience of goodness, truth, and beauty & 22 & 21,36 \\
\hline 7. & Self-transcendence, overcoming one's limitations & 6 & 14,56 \\
\hline 8. & Others & 3 & 5,83 \\
\hline
\end{tabular}

* The sum of the percent values exceeds $100 \%$ because the question was a multiple-choice one. Source: the authors' own data. 
The data on the sources of difficulties during remission are presented in Table 4 . The time when cancer goes into remission is subjectively difficult and complicated to patients who experience it. Therefore, to successfully cope with the illness process, it is important to get to know the sources of experiences which, apart from discomforts directly related to the disease, present difficulties to patients. In the present study, the respondents indicated waiting for control tests and their results (53.40\%) and fear of relapse $(50.49 \%)$ as the most serious additional difficulties.

Table 4

\section{Sources of difficulties during remission}

Таблица 4

Источники трудностей во время ремиссии

\begin{tabular}{|c|l|c|c|}
\hline Rank & \multicolumn{1}{|c|}{ Sources of difficulties during remission } & $\mathbf{N}=103$ & $\%^{*}$ \\
\hline 1. & Waiting for control tests and their results & 55 & 53,40 \\
\hline 2. & Fear of relapse & 52 & 50,49 \\
\hline 3. & Loneliness & 9 & 8,74 \\
\hline 4. & No support from family members & 8 & 7,77 \\
\hline 5. & Feeling of low self-value & 3 & 2,91 \\
\hline 6. & Feeling of being rejected, misunderstood & 2 & 1,94 \\
\hline 7. & Others & 6 & 5,83 \\
\hline
\end{tabular}

* The sum of the percent values exceeds $100 \%$ because the question was a multiple-choice one.

Source: the authors' own data.

Table 5 shows the results concerning the changes in life of the respondents during cancer remission. In connection with the experience of cancer, 42 (40.78\%) respondents changed their attitude to themselves and accepted their limitations, while 40 (38.83\%) respondents changed their value hierarchy. Analysis of the study results also shows that 29 (28.16\%) of respondents changed their attitude to their family and 27 (26.21\%) respondents changed their attitude to God. The experience of the sense of meaning in life in the context of the experience of cancer remission is reflected in further results: 18 (17.47\%) respondents began to think about meaning in their lives, 11 (10.68\%) respondents lost the meaning in life due to the disease, while 6 (5.83\%) respondents started reflecting on and searching for meaning in life. Three (2.91\%) respondents declared that, as a result of their illness, they experienced an increased need to help other people, a greater understanding and readiness to support other patients, as well as the feeling that a disease could make one stronger and that another person might be a 'gift'.

\section{Cancer-related changes in the lives of the respondents}

Table 5

Связанные с раком изменения в жизни респондентов

\begin{tabular}{|c|c|c|c|}
\hline Rank & Cancer-related changes in the life of the respondents & $\mathbf{N}=103$ & $\%^{*}$ \\
\hline 1. & Attitude to self, acceptance of one's limitations & 42 & 40,78 \\
\hline 2. & Value hierarchy & 40 & 38,83 \\
\hline 3. & Attitude to family & 29 & 28,16 \\
\hline 4. & Attitude to God & 27 & 26,21 \\
\hline 5. & I started thinking about the meaning in my life & 18 & 17,48 \\
\hline 6. & I lost the meaning of my life & 11 & 10,68 \\
\hline 7. & I started seeking meaning in my life & 6 & 5,83 \\
\hline 8. & Others & 3 & 2,91 \\
\hline
\end{tabular}

The sum of the percent values exceeds $100 \%$ because the question was a multiple-choice one. Source: the authors' own data. 
An important complement of the above statistical analyses is a detailed analysis of the experience of purpose and meaning in the lives of the respondents. The results for the particular PIL test scales in the studied female and male patients are presented in Table 6.

\section{Mean PIL scales values according to gender of the respondents}

Table 6

Средние значения шкал PIL в зависимости от пола респондентов

Таблица 6

\begin{tabular}{|l|c|c|c|c|c|c|c|}
\hline \multicolumn{1}{|c|}{ PIL subscales } & Gender & Mean & SD & Median & Min & Max & p \\
\hline Goals in life & W & 5,44 & 1,08 & 5,6 & 1,4 & 7,0 & $\mathrm{p}=0,019$ \\
\hline & M & 4,74 & 1,22 & 4,8 & 2,6 & 6,6 & \\
\hline Meaning of life & W & 5,22 & 1,23 & 5,33 & 1,33 & 7,0 & $\mathrm{p}=0,017$ \\
\hline & M & 4,37 & 1,66 & 4,33 & 1,33 & 7,0 & \\
\hline Affirmation of life & W & 4,99 & 1,37 & 5,33 & 1,33 & 7,0 & $\mathrm{p}=0,03$ \\
\hline & M & 4,16 & 1,71 & 4,33 & 1,67 & 6,67 & \\
\hline Self-evaluation & W & 5,35 & 1,04 & 5,5 & 3,0 & 7,0 & $\mathrm{p}=0,047$ \\
\hline & M & 4,76 & 1,4 & 5,0 & 1,5 & 7,0 & \\
\hline Evaluation of one's life & W & 5,51 & 1,25 & 5,5 & 1,0 & 7,0 & $\mathrm{p}=0,565$ \\
\hline & M & 5,32 & 1,12 & 5,5 & 2,5 & 7,0 & \\
\hline Freedom and responsibility & W & 5,11 & 1,38 & 5,0 & 1,0 & 7,0 & $\mathrm{p}=0,164$ \\
\hline & M & 4,59 & 1,54 & 4,5 & 1,5 & 7,0 & \\
\hline $\begin{array}{l}\text { Attitude to death and } \\
\text { suicide }\end{array}$ & W & 4,63 & 1,73 & 5,0 & 1,0 & 7,0 & $\mathrm{p}=0,646$ \\
\hline & M & 4,41 & 1,97 & 5,0 & 1,0 & 7,0 & \\
\hline
\end{tabular}

Source: the authors' own data.

The conducted research project has made it possible to achieve the aim set by the authors, who obtained answers concerning the level and specific characteristics of the experience of meaning and purpose in life and their connection with the sense of coherence in the studied patients after the completion of their cancer treatment.

Analyzing the scores on all the PIL scales in the group of studied women and men found that the profile of results falls within the range of mean values. The minimum value was obtained by men on the affirmation of life scale $(M=4.16)$, while the maximum value was recorded in women on one's life evaluation scale $(\mathrm{W}=5.51)$.

Statistically significant differences between the studied women and men were found in the following scales: goals in life $(p=0.02)$, meaning in life $(p=0.02)$, affirmation $(\mathrm{p}=0.03)$ and self-evaluation $(\mathrm{p}=0.05)$. Basing on the obtained results, it is possible to conclude that the studied women $(\mathrm{W}=5.44)$ in cancer remission have more intense experience of goals in their lives than the men $(\mathrm{M}=4.74)$, and thus their sense of the meaning of life is greater $(\mathrm{W}=5.22)$ than that of men $(\mathrm{M}=4.37)$. The women accept the time of remission with a greater degree of affirmation $(\mathrm{W}=4.99)$ than the men do $(\mathrm{M}=4.16)$ and their self-evaluation is higher ( $\mathrm{W}=5.35)$ than the men's $(M=4.76)$.

No statistically significant differences with respect to gender were obtained in the following scales: evaluation of one's life, freedom/responsibility, and attitude to death and suicide. In this connection, it may be stated that during remission, freedom and responsibility at an average level $(\mathrm{W}=5.11$, $\mathrm{M}=4.59$ ) and attitude to death and suicide $(\mathrm{W}=4.63, \mathrm{M}=4.41$ ) are experienced by both the women and the men in the study group at an average level. The results also show that the reality of death, inherent in the life of a human being, is not associated by the respondents with anxiety or escape from life, nor does it 
inspire suicidal ideation. Such evaluation of the situation of illness helps to assume the attitude of distance realistic approach to difficulties related to the illness process.

Another stage of the study concerned the respondents' sense of coherence and its components. Table 7 presents detailed data. The research showed that in the studied group of survivors the sense of coherence and manageability was at an average level, while the sense of meaningfulness was increased. The age of the respondents, their education, place of residence, marital status, number of children, and relationships with others did not affect either the sense of comprehensibility or that of manageability.

SOC-29 results in the study group

Table 7

Таблица 7

Результаты SOC-29 в исследуемой группе

\begin{tabular}{|l|c|c|c|c|c|c|c|}
\hline \multicolumn{1}{|c|}{ Variable } & Mean & SD & Median & Min & Max & 1st quartile & 3rd quartile \\
\hline Comprehensibility & 4,17 & 0,96 & 4,18 & 2 & 6,45 & 3,45 & 4,86 \\
\hline Manageability & 4,63 & 4,63 & 4,6 & 2,3 & 6,6 & 4,05 & 5,3 \\
\hline Meaningfulness & 5,04 & 1,09 & 5,12 & 2,38 & 6,75 & 4,38 & 5,81 \\
\hline
\end{tabular}

Source: the authors' own data.

At the same time, the sense of meaningfulness was not significantly influenced by marital status and education, while the age of the respondents and the place of residence were significantly correlated $(\mathrm{p}<0.001, \quad \mathrm{p}=0.09$, respectively) with meaningfulness.
The correlations between the relationship with family and achieving goals and experiencing meaning in life by the respondents are presented in Table 8.

Effect of the relationships with one's family on the purpose

Table 8 in life (PIL) and the sense of coherence (SOC)

Влияние отношений с семьей на цель в жизни (PIL) и чувство согласованности (SOC)

\begin{tabular}{|l|c|c|c|}
\hline \multirow{2}{*}{\multicolumn{1}{|c|}{ Subscales PIL/SOC }} & \multicolumn{2}{c|}{ Correlation with the relationships with one's family } \\
\cline { 2 - 4 } & Correlation coefficient & $\mathbf{p}$ & $\begin{array}{c}\text { Direction of the } \\
\text { correlation }\end{array}$ \\
\hline Goals in life (PIL) & 0,366 & 0,001 & Positive \\
\hline Meaning of life (PIL) & 0,272 & 0,005 & Positive \\
\hline Affirmation of life (PIL) & 0,323 & 0,001 & Positive \\
\hline Self-evaluation (PIL) & 0,225 & 0,023 & Positive \\
\hline Evaluation of one's life (PIL) & 0,304 & 0,002 & Positive \\
\hline Freedom and responsibility (PIL) & 0,227 & 0,021 & Positive \\
\hline Attitude to death and suicide (PIL) & $-0,029$ & 0,773 & Positive \\
\hline Comprehensibility (SOC) & 0,277 & 0,005 & Positive \\
\hline Manageability (SOC) & 0,36 & 0,001 & Positive \\
\hline Meaningfulness (SOC) & 0,263 & 0,007 & \\
\hline
\end{tabular}

Source: the authors' own data. 
The variable 'relationships with family' during cancer remission significantly affects seeking goals in live $(p=0.001)$, experience of the meaning of life $(\mathrm{p}=0.005)$, affirmation of life during remission $(\mathrm{p}=0.001)$, selfevaluation ( $p=0.023)$, evaluation of one's life $(p=0.002)$, and the experience of freedom and responsibility $(p=0.021)$. The statistically significant correlation found in the study is positive, which makes it possible to conclude that good, warm, and close relationships with one's family members positively influence the perception of different aspects of the experience of meaning and purpose in the respondents' lives. The relationships with family do not significantly affect the respondents' attitude to death or suicidal ideation.

The above results also indicate that the relationships with family exert a statistically significant influence on all components of the sense of coherence: comprehensibility $(p=0.005)$ manageability $(p=0.001)$, and meaningfulness $(p=0.007)$. These statistically significant correlations are also positive. It may be thus concluded that the quality of the relationships with family and close ones has a positive effect on shaping the appropriate sense of coherence, which translates into coping well with difficult situations. The level of manageability and of the ability to cope with a stressful situation, such as experience of cancer, is related to looking for possible new solutions, and professional medical help and support. The ability to perceive a meaning in the situation of illness depends on the level of support obtained from close ones, knowledge the patients have and information they obtain about their situation, as well as their understanding of that situation.

\section{Discussion}

Cancer remission is a situation in which the studied individuals experienced difficulties and changes in their life. They often feel great uncertainty and suffer from lack of the sense of security. The respondents indicated waiting for control tests and their results and fear of a relapse as the most serious difficulties. During remission, a majority of the respondents changed their attitude towards themselves, accepted their limitations, and changed their hierarchy of values, and also their attitude to their family and to God. The study by Wiraszka and Lelonek point to the fact that difficulties and limitations due to cancer are a source of disorders in different spheres of an individual's functioning, thus leading to various changes in the life of a suffering person [13; 17].

The post-therapy care over cancer patients based on Watson's human caring model, which involves spirituality, was found to reduce side effects of cancer treatment [18]. Providing spiritual care as an integral part of looking after the patient and his or her family helps to reduce stress and ease the process of recovery $[19 ; 20 ; 21]$.

Our research confirmed that health is considered as the greatest value in human life, especially after the experience of cancer. It is physical health and spiritual fulfillment that enable a person to live a satisfying and meaningful life [22].

The level of experience of the purpose and meaning of life was found to be different in women and men. As the research showed, women had a significantly higher sense of life's purpose and meaning than men, showed a significantly higher affirmation of their lives, and also reported a significantly higher self-evaluation (t-Student test $\mathrm{p}$ below 0.05 ; the mean value higher in women). The purpose in life is a basic component of promoting life satisfaction in persons with an experience of cancer [23]. The meaning of life plays a key role in the relationship between self-acceptance and psychological well-being [24].

Contacts with the closest members of one's family and with other people exert a statistically significant influence on the level of achieved goals and perceived meaning of life on the one hand and the sense of 
coherence on the other. Research showed that the better the relationships with one's family, the higher the sense of purpose and meaning in life, and the greater affirmation of it, the better self-evaluation and the greater sense of freedom and responsibility are. Patients, whose family relationships are positive, are characterized with a dynamic sense of coherence in all its components: comprehensibility described as a cognitiveinformation dimension of the ability to liver through difficult situations $(p=0.005)$; manageability, which is the instrumentalactive component $(\mathrm{p}=0.001)$, and meaningfulness, which indicates the patient's emotional-motivational commitment to coping with illness $(p=0.007)$. Following the research and observations by Antonovsky, reported by Michalak, we assume that that an important or difficult event in life (in this case, cancer) may strengthen the sense of coherence [25] which, in turn, may become a 'protective buffer' and 'meta-resource' in experiencing a stress situation such as cancer [26]. The research by Dymecka has found that the sense of coherence plays the role of a 'moderator', which protects individuals from destructive effects of difficult situations they experience in their lives; this function is particularly important for cancer patients' families [27; 28].

Spirituality should be considered as a resource to support adaptation and resilience and thus possibly improve the quality of life of persons who experienced cancer [29]. For some patients, their faith in themselves, others, and God constitute the meaning, or purpose, of their lives [30]. Positive effects of optimism and social support also show a positive correlation with spiritual coping [31].
Our study is an important contribution to the discussion about the spiritual aspect of care in oncology. The conclusions we present below may become signposts in planning the path of recovery for oncological patients, from diagnosis to remission.

Hypotheses 1 were confirmed. A good quality of relationships in family is an important factor which strengthens a person in the process of coping with the disease.

Hypotheses 2 were confirmed. Health, love, and relationships with close people are the most important values motivating patients during the disease.

Hypotheses 3 were confirmed. During remission, cancer patients experience difficulties related to waiting for control tests and their results, fear of relapse, a sense of being lonely and a low feeling of security. The studied patients radically changed, among others, their attitude to illness-related limitations, their value hierarchy and their attitude to their family and to the meaning of their lives.

Hypotheses 4 were confirmed. The studied women differ from the men with respect to the level of seeking goals and meaning in life, affirmation of life, as well as self-evaluation. No differences between women and men were found with respect to evaluation of their lives, experience of freedom and responsibility, attitude to death, as well as a risk of suicidal ideation.

Hypotheses 5 were confirmed. The level of family relationships significantly affects the level of purpose and meaning in the lives of the studied patients and their sense of coherence. 
Lilia Suchocka, Katarzyna Jaroszek, Elena Medvedeva,

Information about the authors:

Suchocka Lilia, Doctor of Psychology, Professor, Jan Kochanowski University of Kielce, Faculty of Education and Psychology, Kielce, Poland.

Contact information: e-mail: liliasuchocka@ibnps.eu; ORCID: 0000-0003-0474-3955.

Jaroszek Katarzyna, Master of Science in Nursing, University of Applied Sciences in Tarnow, Tarnow, Poland.

Contact information: e-mail: s.katarzynaj@interia.pl

Pasek Małgorzata, Doctor of Medical Sciences, Professor, Department of Nursing, University of Applied Sciences in Tarnow, Tarnow, Poland.

Contact information: e-mail: malgorzata_pasek@wp.pl; ORCID: 0000-0002-5638-5582; Researcher ID Web of Science: ABI-7405-2020.

Medvedeva Elena, Doctor of Economics, Professor, Leading Researcher, Institute of Socio-Economic Studies of Population of the Federal Center of Theoretical and Applied Sociology of the Russian Academy of Sciences; Moscow, Russian Federation.

Contact information: e-mail: e_lenam@mail.ru; ORCID: 0000-0003-4200-1047; Researcher ID Web of Science: B-8964-2018; Elibrary Author ID: 381176.

Szczepanik Angelika, Master of Psychology, Institute of Biofeedback and Noo-psychosomatic, Lublin, Poland.

Contact information: e-mail: angelikaszszczepanik@gmail.com; ORCID: 0000-0002-1943-0444.

\title{
КАЧЕСТВО И СМЫСЛ ЖИЗНИ ОНКОБОЛЬНЫХ ЛЮДЕЙ В ПЕРИОД РЕМИССИИ: СОЦИАЛЬНО-ПСИХОЛОГИЧЕСКИЕ АСПЕКТЫ
}

\author{
Лилия Сухоцка ${ }^{1}$, Екатерина Ярошек ${ }^{2}$, \\ Елена Медведева ${ }^{3 *}$, Анжелика Щепаник ${ }^{4}$, Маргарита Пасек ${ }^{2}$ \\ ${ }^{1}$ Jan Kochanowski University of Kielce \\ (ul. Żeromskiego 5, Kielce, Poland, 25-369) \\ ${ }^{2}$ University of Applied Sciences in Tarnow \\ (ul. Mickiewicza 8, Tarnow, Poland, 33-100) \\ ${ }^{3}$ Институт социально-экономических проблем народонаселения ФНИСЦ РАН \\ (117218, Россия, Москва, Нахимовский проспект, 32) \\ ${ }^{4}$ Institute of Biofeedback and Noo-psychosomatic \\ (ul. Farmaceutyczna 13, Lublin, Poland, 20-706) \\ *E-mail: e_lenam@mail.ru
}

\section{Для цитирования:}

Сухоцка Л., Ярошек Е., Медведева Е., Щепаник А., Пасек М. Качество и смысл жизни онкобольных людей в период ремиссии: социально-психологические аспекты // Народонаселение.- 2021.T. 24. - № 3. - C. 76-91. DOI: 10.19181/population.2021.24.3.7. 
Аннотация. Чувство смысла жизни определяется как субъективно ощущаемое, а также позитивное и психическое состояние. Страдание при хроническом заболевании усиливает учеловека состояние изоляции, порождает чувства, с которыми он часто не может справиться. Такие ощущения очень характерны в процессе ремиссии онкологического заболевания. Чувство когерентности и согласованности усиливает состояние борьбы с болезнью, что может способствовать позитивному тренду на выздоровление. В статье представлены результаты авторских исследований (103 респондента), по вопросам качества и смысла жизни онкобольных людей в период ремиссии: социально-психологические аспекты, индикаторы категорий «смысла жизни», «ответственности», «согласованности», причем последнее является доминантным на этапе ремиссии рака у исследуемых когорт. Опрос проводился на основе разработанной авторами методики с использованием теста «Цель в жизни» (PIL) Дж. К. Крамбо и Дж. Махолика, а также «Чувство согласованности» А. Антоновского (SOC-29). Исследование показало, что в изучаемой группе довольно высокий уровень индикаторов категорий «смысл жизни», «ответственность», «согласованность», которые не зависели от того, когда у респондентов был диагностирован рак, а также тот факт, что исследуемые показатели достигали более высоких значений уженщин, чем у мужчин. Были выделены межличностные факторы: «смысл жизни» и «ответственность» как доминирующие при исследовании качества и смысла жизни по отношению к другим социально-психологическим факторам. Самыми важными ценностями, которые мотивируют пациентов в процессе болезни, являются: здоровье, любовь и отношения с родственниками.

Ключевые слова: социально-психологические факторы, качество жизни, смысл жизни, чувство ответственности, ремиссия, здоровье.

\section{Литература и Интернет-источники / References and Internet sources}

1. Wojciechowska U., Didkowska J., Michałek I., Olasek P., Ciuba A. Nowotwory złośliwe w Polsce w 2018 [Cancer in Poland in 2018]. Krajowy Rejestr Nowotworów [Polish National Cancer Registry]. Warszawa. 2020. ISSN0867-8251. (in Polish)

2. Krakowiak P. Make It to the Truth. Gdansk. Via Medica. 2006.

3. Семиглазова, T.Ю. Международная модель реабилитации онкологических больных / Т.Ю. Семиглазова, В.А. Клюге, Б.С. Каспаров, К.О. Кондратьева, А.А. Крутов, М.А. Зернова, В.А. Чулкова, В.В. Семиглазов. // Медицинский Совет.- 2018. - № 10.-С. 108-116. / Semiglazova T. Yu., Klyuge V.A., Kasparov B.S., Kondratieva K.O., Krutov A.A., Zernova M.A., Chulkova V.A., Semiglazov V.V. An international model of cancer patients' rehabilitation. Medical Council. 2018. No. 10. P. 108-116. DOI: 10.21518/2079-701X-2018-10-108-116. (in Russ.)

4. Солопова, A.Г. Психосоматика и психотерапия как ключ к эффективной реабилитации онкогинекологических больных / А. Г Солопова, Л.Э. Идрисова, А.Д. Макацария, Е. М. Чуканова // Акушерство, гинекология и репродукция. - 2017.- № 11(1).-C. 65-73. / Solopova A.G., Idrisova L.E., Makazaria A.D., Chukanova E.M. Psychosomatics and Psychotherapy as a key to effective rehabilitation of cancer patients. Obstetrics, Gynecology and Reproduction. 2017. No. 11(1). P. 65-73. DOI: 10.17749/2313-7347.2017.11.1.065-073. (in Russ.)

5. Łuczak J., Kotlińska-Lemieszek A., Bączyk E. Somatic aspects of suffering. Modern Oncology. 2000. Vol. 4-5. P. 224-230.

6. Frankl V.E. Man in Search of Meaning. Warsaw. Black Sheep Publishing House. 2010.

7. Popielski K. Man - Open Question. Lublin. KUL Publishing House. 1987.

8. Popielski K. Noetic Personality Dimension. Lublin. Institute of Biofeedback and Noo-psychosomatic. 2018. 
9. Patyjewicz L. Health and the sense of meaning of life. Annales Universitatis Mariae CurieSkłodowska. Lublin. Sectio D Medicina. Vol. LX. Suppl. XVI. 2005. P. 392, 250-264.

10. De Walden-Gałuszko K. Nursing in Palliative and Hospice Care. Warsaw. Medical Publishing House PZWL. 2005.

11. Suchocka L. Psychological Analysis of Suffering in Chronic Disease. Lublin. TN KUL. 2008.

12. John Paul II. Apostolic Letter Salvifici Doloris, on the Christian Sense of Human Suffering. Roma. 1984.

13. Kübler-Ross E. Conversations about Death and Death. Poznan. Media Family. 2007.

14. Antonovsky A. The structure and properties of the Sense of Coherence Scale. Social Science \& Medicine. 1993. Vol. 36 (6). P. 725-733.

15. Antonovsky A. Unravelling the Mystery of Health. How to Deal with Stress and not get Sick. Warsaw. Institute of Psychiatry and Neurology. 2007.

16. Antonovsky H., Sagy S. The development of a sense of coherence and its impact on responses to stress situations. The Journal of Social Psychology. April 1986. No. 126(2). P. 213-25.

17. Wiraszka G., Lelonek B. Functioning of a leukemia patient and acceptance of cancer. Medical Studies. 2008. Vol. 10. P. 21-26.

18. Aktürk Ü., Erci B. The effect of Watson's human caring model on meaning of life and symptom management in cancer patients undergoing chemotherapy. Research and Theory for Nursing Practice. August 2018. No. 32(3). P. 255-275. DOI: 10.1891/1541-6577.32.3.255.

19. Best M., Leget C., Goodhead A., Paal P. An EAPC white paper on multi-disciplinary education for spiritual care in palliative care. BMC Palliative Care. 15 Jan. 2020. No. 19(1). P. 9. DOI: 10.1186/ s12904-019-0508-4.

20. Trevino K.M, Naik A.D., Moye J. Perceived and actual change in religion/spirituality in cancer survivors: Longitudinal relationships with distress and perceived growth. Psychology of Religion and Spirituality. Aug. 2016. No. 8(3). P. 195-205. DOI: 10.1037/rel0000030.

21. Yeary K.H.K., Alcaraz K.I., Ashing K.T., Chiu C., Christy S. M., Felsted K.F., Lu Q., Lumpkins C. Y., Masters K. S., Newton R.L., Park C.L., Shen M. J., Silfee V.J., Yanez B., Yi J. Considering religion and spirituality in precision medicine. Translational Behavioral Medicine. 3 Feb. 2020. No. 10(1). P. 195203. DOI: $10.1093 / \mathrm{tbm} / \mathrm{ibz} 105$.

22. Xia H.Z., Gao L., Yue H., Shi B.X. Exploring meaning in the life of Chinese breast cancer survivors. Cancer Nursing. Mar./Apr. 2018. No. 41(2). P. 124-130. DOI: 10.1097/NCC.0000000000000466.

23. Teques A.P., Carrera G.B., Ribeiro J.P., Teques P., Ramón. G.L. The importance of emotional intelligence and meaning in life in psycho-oncology. Psycho-Oncology. March 2015. No. 25(3). P. 324-31. DOI: 10.1002/pon.3921.

24. Zhou Y., Xu W. Short report: the mediator effect of meaning in life in the relationship between selfacceptance and psychological wellbeing among gastrointestinal cancer patients. Psychology Health and Medicine. July 2019. No. 24(6). P. 725-731. DOI: 10.1080/13548506.2018.1554252.

25. Michalak A. On the way to health - concept of salutogenesis and feeling of coherence by Aaron Antonovsy. Psychology. Ed. Trzcienieckie - Green A. Cracow. Universitas. 2006.

26. Vachon M.L. Meaning, spirituality, and wellness in cancer survivors. Seminars in Oncology Nursing. Aug. 2008. No. 24(3). P. 218-25. DOI: 10.1016/j.soncn.2008.05.010.

27. Kulczycka-Dopiera A. Feelings of coherence and spirituality-factors protecting against burnout of people who are engaged in medical and psychosocial assistance to cancer patients. Preliminary reports. Psycho-Oncology. 2014. No. 2. P. 59-65.

28. Dymecka J. A sense of coherence and the state of health of parents struggling with the oncological disease of the child. Psycho-Oncology. 2013. No. 1. P. 16-22.

29. Yilmaz M., Cengiz H.Ö. The relationship between spiritual well-being and quality of life in cancer survivors. Palliative and Supportive Care. Feb. 2020. No. 18(1) P. 55-62. DOI: 10.1017/ S1478951519000464. 
30. Hunter-Hernández M., Costas-Muñíz R., Gany F. Missed opportunity: Spirituality as a bridge to resilience in Latinos with cancer. Journal of Religion and Health. Dec. 2015. No. 54(6). P. 2367-2375. DOI: 10.1007/s10943-015-0020-y.

31. Ciria-Suarez L., Calderon C., Fernández Montes A., Antoñanzas M., Hernández R., Rogado J., PacheoBarcia V., Ansensio-Martínez E., Palacín-Lois M., Jimenez-Fonseca P. Optimism and social support as contributing factors to spirituality in Cancer patients. Supportive Care in Cancer. 3 Jan. 2021. DOI: $10.1007 / \mathrm{s} 00520-020-05954-4$.

\section{Сведения об авторах:}

Сухоцка Лилия, к.псх.н., проф., факультет образования и психологии Кельцского университета имени Яна Кохановского, Кельц, Польша.

Контактная информация: e-mail: liliasuchocka@ibnps.eu; ORCID: 0000-0003-0474-3955.

Ярошек Екатерина, магистр медицины, Государственная Высшая Профессиональная школа в Тарнове, Тарнов, Польша.

Контактная информация: e-mail: s.katarzynaj@interia.pl.

Пасек Маргарита, к.м.н., проф., Государственная Высшая Профессиональная школа в Тарнове, Тарнов, Польша.

Контактная информация: e-mail: malgorzata_pasek@wp.pl; ORCID: 0000-0002-5638-5582; Researcher ID Web of Science: ABI-7405-2020.

Медведева Елена, д.э.н., проф., ведущий научный сотрудник, Институт социально-экономических проблем народонаселения Федерального научно-исследовательского социологического центра Российской академии наук, Москва, Россия.

Контактная информация: e-mail: e_lenam@mail.ru; ORCID: 0000-0003-4200-1047; Researcher ID Web of Science: B-8964-2018; РИНЦ Äuthor ID: 381176.

Щепаник Анжелика, магистр психологии, Институт биологической обратной связи и ноо-психпсоматики, Люблин, Польша.

Контактная информация: e-mail: angelikaszszczepanik@gmail.com; ORCID: 0000-0002-19430444.

Статья поступила в редакцию 25.05.2021, одобрена 30.08.2021, опубликована 30.09.2021. 